\title{
Prevalence of household food insecurity in wetland adjacent areas of Uganda
}

\author{
Fred Yikii ${ }^{1} 2^{*}$ (D) Nelson Turyahabwe ${ }^{3}$ and Bernard Bashaasha ${ }^{4}$
}

\begin{abstract}
Background: Food insecurity is a critical problem affecting about $6.3 \%$ of the households in Uganda, with about $21 \%$ of the remaining households on the brink of becoming food insecure due to poverty, inequality and droughtrelated extreme weather events. Until recently, studies have shown that the semi-arid areas of Uganda experience food insecurity more than other parts of the country. Although wetlands significantly contribute to food security, over $80 \%$ of the households inhabiting wetland adjacent areas in Uganda are perceived to be food insecure. The purpose of this study was therefore to determine the prevalence of food insecurity in the wetland adjacent areas of Uganda and the socio-economic and demographic factors that influence household food insecurity in these areas.
\end{abstract}

Methods: A cross-sectional survey of 520 households was conducted in areas adjacent to wetlands in Uganda. Oneway analysis of variance and Chi-square test of independence were conducted to determine the association between the socio-economic and demographic characteristics of households and household food security status.

Results: The study revealed that about 93\% of the households in the wetland areas of Uganda were food insecure. Household food insecurity in these areas was significantly associated with the wetland systems, living in a permanent house, group membership and off-farm employment of the household head. Households with fewer adult members were significantly food secure compared with those with more adults. In addition, households headed by educated people were significantly food secure compared with those headed by less educated people.

Conclusions: Households in the wetland areas in Uganda are generally food insecure, the primary reasons being poverty, low labour productivity (and/or unemployment), and low levels of education. Unless government and civil society promote food and nutrition education, income generating activities, drought resistant crop varieties and water conservation to farmers, food insecurity in wetland areas in Uganda could further drive wetland degradation, malnutrition and public health challenges.

Keywords: Household, Food security, Food insecurity, Wetland areas, Uganda

\section{Background}

Food security continues to feature prominently in global development agenda because of the persistence of food insecurity in many parts of the world, most especially the developing countries. It is estimated that 780 million people out of the 795 million undernourished people in the world live in developing countries [1]. Recent estimates indicate that the number of undernourished

\footnotetext{
*Correspondence: fyikii@gmail.com

1 Department of Forestry, Biodiversity and Tourism, School of Forestry,

Environmental and Geographical Sciences, Makerere University, P.O

Box 7062, Kampala, Uganda

Full list of author information is available at the end of the article
}

people in the world increased from 777 million in 2015 to 815 in 2016 [2]. In the sub-Saharan Africa (SSA), the number of undernourished people has grown by 44 million between 1990 and 2016, despite a projected reduction in their proportion in the region from 33 to $23 \%$ in the same period [1]. Worse still, about $34 \%$ of the population in Eastern Africa is undernourished [2]. Predictably, given the low level of economic advancement, high disease burden, rampant unemployment and low labour productivity in the SSA; a high level of food insecurity prevails in the region $[1,2]$ at a time when global food production is sufficient to feed everyone [3]. Following [4], this is a clear indication that food insecurity at the 
moment is rather a problem of limited access to food than a lack of food supplies.

Food insecurity among the inhabitants of wetland areas is of major concern from environmental and public health perspectives. From the environmental health point of view, food production in wetlands significantly contributes to degradation of wetlands, the implications being biodiversity and wetland loss. As [3] put it, food insecurity and biodiversity loss are global problems that go hand in hand in that efforts to address one of them generally trigger the other and vice versa. Typically, the Millennium Ecosystem Assessment (MEA) report [5] revealed that the degradation and loss of wetlands exceed that of all other ecosystems mainly due to their use for agriculture and food production. Indeed, several studies $[6,7]$ have shown that wetlands are used in various ways to attain food security mostly in communities neighbouring the wetlands. Other studies [8] go further to concur that the use of wetlands for food security is the primary reason for wetland degradation and loss. Therefore, there is a growing concern that if this trend is left to continue, significant wetland resources will be destroyed [5].

Food insecurity in wetland areas is also a cause of concern from the perspective of public health. First of all, by virtue of their ecological character, wetlands are a habitat for vectors that carry disease-causing pathogens, thus transmitting both livestock and human diseases such as malaria and schistosomiasis (bilharzia) [9]. There are also human diseases such as HIV/AIDS and syphilis that are not in any way waterborne but are highly prevalent in communities adjacent to water resources, including wetland areas. As [10], for example, found out, the prevalence of HIV/AIDS among fishing communities in Lake Victoria was $29 \%$ and peaking at $40 \%$ among women, while the national average at the time of their study was $6.4 \%$. Apparently, disease increases vulnerability to food insecurity, as the economic burden of treatment diverts resources that would otherwise be invested in food security [11, 12]. Ill health also impairs or even completely detains the labour of patients [13], including that of caregivers much needed for productive activities. Therefore, the high prevalence of diseases in these areas is a major concern for food insecurity in wetland communities. On the other hand, food insecurity particularly renders fishing communities vulnerable to sexually transmitted infections (STIs) because the unreliable income among both men and women prompts risky behaviours such as transaction of sex for food such as fish especially by women [10]. Unfortunately, since fishing communities in Uganda have not received adequate public health services despite the high prevalence of HIV/AIDS in these areas [10], broader public health issues in wetland areas remain unclear.
Food security exists "when all people, at all times, have physical, social and economic access to sufficient, safe and nutritious food that meets their dietary needs and food preferences for an active and healthy life" [14]. Food security that addresses household access to food has remained important ever since Amartya Sen attributed food insecurity to social and economic inequalities [4]. Other than ensuring food security as a livelihood outcome in itself [15], access to food at the household level is an important measure of household welfare [16]. In contrast, food insecurity refers to the limited or uncertain availability of nutritionally adequate, safe foods or the inability to acquire personally acceptable foods in socially acceptable ways [17]. Food insecurity is associated with poverty, ill health, depressive disorders, limited social capital and poor dietary intake [18].

Household access to food is realized through various means: (1) own food production by the households; (2) purchase of food from the markets; (3) exchange of food for other resources; (4) food aid or donations; and (5) any other sources such as collection of food resources from the wild. The means employed to access food depends on the availability of resources and the economic system of a country [4]. Ultimately, whether a household is food secure or food insecure is highly dependent on its composition [19, 20] and financial circumstances [20]. Studies $[6,21]$ have shown that poverty and other forms of inequality heavily influence household dependence on wetlands for food security.

In Uganda, where a significant proportion of households $(6.3 \%)$ are food insecure, and about $21 \%$ of the remaining households are on the brink of food insecurity [22]; food insecurity has been attributed to poverty and other forms of inequality [23], and drought-related extreme weather events of late. Although agricultural households produce the bulk of the foods locally consumed in Uganda, the Uganda Bureau of Statistics (UBOS) $[24,25]$ reported that about $56 \%$ of the 3.6 million agricultural households that participated in the Uganda Census of Agriculture 2008/2009 had experienced food shortage in the survey reference period. Even though several studies of food security have been conducted in Uganda, there is limited information on the status of food security in wetland communities in the country. Only recently, [6] investigated the contribution of wetlands to food security with a focus on household perception and experiences of food insecurity, and how they used wetlands to improve their food security. Apparently, they found that over $80 \%$ of the households in wetland areas in the three agro-ecological zones covered by the study had experienced food insecurity in the 5 years preceding their study. 
Considering that household food insecurity in Uganda is more prevalent in the semi-arid Karamoja region than the other regions of the country [22], coupled with the current ascendancy of drought-related climate change in explaining food insecurity, it appears to be taken for granted that people in wetland areas are food secure. The historical regard of wetlands in Uganda as wastelands [26] could be responsible for the seemingly low concern for food security in wetland areas among researchers. In addition, the fact that the wetland policy for Uganda generally allows traditional use of wetlands might have been perceived by authorities as a window of opportunity open enough for inhabitants of wetland areas to ensure their food security.

In light of these views, the present study aimed at assessing the socio-economic and demographic factors that influence household food security in wetland areas in Uganda. Specifically, the study set out to: (1) determine the prevalence of household food insecurity in the wetland areas in Uganda and (2) determine the socio-economic and demographic factors that influence household food insecurity in the wetland adjacent areas in Uganda.

Information on the status of food security is useful for designing policies and programmes for addressing the problem of food insecurity [27, 28]. At the same time, being wetland communities, this information is useful for designing policies for sustainable management of wetland resources. Ultimately, the information generated in this study contributes to achievement of the following sustainable development goals (SDGs): (goal 2) end hunger, achieve food security and improved nutrition and promote sustainable agriculture; (goal 6) ensure availability and sustainable management of water and sanitation for all; and by extension (goal 1) end poverty in all its forms everywhere [29].

\section{Selection of the study sites}

The study was carried out in wetland areas adjoining Lake Nakivale wetland system in Isingiro District and wetlands in Lake Kyoga basin but within Pallisa District (Fig. 1). Similar to [6], the two sites were selected for this study to represent two agro-ecological zones along the cattle corridor that differ by farming system. Isingiro District is located in south-western Uganda within the agro-ecological zone of the south-western farmlands. Farming in this zone is dominated by livestock rearing and banana growing. The agro-ecological zone of Pallisa District is the Kyoga plains characterized by a typical Teso farming system where mixed annual crop production is practised together with livestock production [30]. The wetlands were also selected because of their rural location bearing in mind that agriculture is the main economic activity in these areas. While less than $30 \%$ of the rural populations in Isingiro District are below the poverty line, at least $40 \%$ of those in Pallisa District are in the same category [8]. It is envisaged in this study that such differences in poverty levels influence household access to food. In terms of wetland management, parts of the wetland systems in Pallisa District and Lake Mburo-Nakivale wetland system are Ramsar sites [31].

\section{Research design and sampling procedure}

Data were collected using a cross-sectional survey of households living in parishes in the frontline of wetlands. Respondents were selected from villages within frontline parishes neighbouring Lake Nakivale and Lake Kyoga but located within Pallisa District. Two-stage cluster sampling was used to select respondents to the study. The primary sampling unit was the village, while the secondary sampling unit was the household within the selected villages. A village is the lowest administrative unit of the government of Uganda. A list of villages within parishes that are at least partially covered by wetlands were drawn from the records of villages in the two districts obtained from the district authorities. Twenty-six villages were randomly selected for the study from each district using probability proportional to size sampling technique aided by district and local council authorities. The secondary sampling unit and the unit of analysis for the study was the household because a household is the primary unit of resource holding, production, distribution and consumption [32]. The two commonly used formulae for sample size determination are Krejcie and Morgan (1970) and Cochran's (1977) [33]. A sample size of 520 households for this study was determined using Cochran's (1977) sample size formula described by [33] following [34]. This sample was based on the experiences of prevalence of food insecurity in the wetland areas in Uganda as reported by [6].

\section{Measurement of food security}

Food security was measured using an interaction approach developed by [35] and elaborately described in [27]. Quoting [27], this approach measures "to what extent a proportion of households are insecure on a particular dimension given they are insecure on another dimension". Therefore, consistent with [27, 28], the indicators used for the interaction variable for food security in this study were household dependency ratio and the number of meals consumed by the household in a day.

A common measure of dependency ratio is the demographic dependency ratio that is based on age [36]. For the purposes of explaining economic phenomena, the demographic dependence ratio derives its economic interpretation from the assumption that children and elderly people outside a certain age bracket (which 
varies a lot) are dependents. The obvious limitation of this approach is that not all the people within the supposed working-age bracket are working, while some of those deemed to be dependents are actually working [36]. Based on this measure, as used by [37], while the official working age in Uganda is from 14 to 64 years [37], the Uganda National Population and Housing Census 2014 revealed that $40 \%$ of the population between 10 and 14 years and $66 \%$ of those above 65 years of age were actually working [37]. Thus, use of demographic dependence ratio was considered misleading in this study given its context of wetland adjacency where the official working-age group may be highly deprived of its productivity, for example, by unemployment, health problems, high prevalence of orphanhood, bad habits such as alcoholism or even poor working habits. Although measures of economic dependency described by [38], for example, cater for some of these weaknesses, they still appeared to hold the assumption that people below 14 years of age are all dependents. Besides, the extent of intrusion that may result in the process of gathering information for improving accuracy of economic dependency ratio using variables described by [38] would be high. Subsequently, using the measure employed by [39], household dependency ratio for this study was computed as the proportion of household members that are not working to those that are working. In addition to information on household dependence ratio, respondents were also asked to give the number of meals they consume in a day. Using these variables, the status of household food security was computed as follows: a household with a large number of dependents (dependence ratio is above 0.5) and consuming less number of meals per day (below three meals per day) was considered relatively more food insecure and assigned a value of 3 . On the other hand, a household that had less number of dependents and consumes more meals was considered relatively more food secure and assigned a value of 0 . Household food security categories were then computed on a 0-3 scale where the higher values of the scale (indicator) meant that the household was more food insecure as shown in Table 1.

Data were also collected on household socio-economic and demographic characteristics such as age, sex and education level of the household head. Other attributes of the household such as number of people living in the household, proximity to wetland boundary and proximity to market were also included in the study. The economic attributes of the households included in the study were land size, main occupation of the household head and engagement in crop and livestock production.

To compare the wide range of livestock reared by households, the livestock units owned by the households were standardized by conversion into Tropical Livestock Unit(s) (TLUs) [40]. The following TLU values for different animals assigned by the International Livestock Research Institute (ILRI) [27] were used for computing TLUs in this study: 0.8 for cattle; 0.1 for goat; 0.1 for sheep; 0.2 for pigs; and 0.01 for chicken, ducks and doves. Like other household assets, livestock ownership by households is important for food security because they can be sold to smooth consumption during times of need; as such, they are a good proxy for household income levels [27].

\section{Data analysis}

Descriptive statistics and bivariate analysis were conducted using Stata for Windows (Stata Statistical Software) Release 13 (College Station, TX: StataCorp LP) [41]) and the Statistical Package for Social Science (SPSS) for Windows version 23.0 (SPSS Inc., Chicago, IL, USA) [42]. Microsoft Excel 2007 was used to produce graphs. Descriptive statistics such as frequency, percentage, mean and standard deviations were computed to describe the sample data. Bivariate analysis that comprised one-way analysis of variance and Chi-square test of independence were conducted to determine the association between the socio-economic and demographic characteristics of households and household food security status. Oneway analysis of variance (ANOVA) was used to compare the means of continuous variables, while Chi-square was used to compare categorical variables [34]. Owing to violation of the assumption of homogeneity of variances, the Welch's ANOVA was used to test the differences between household food security and the age of the household head [43]. A Kruskal-Wallis $H$ test and a Dunn's post hoc test with a Bonferroni adjustment were carried out to compare household food security status with household characteristics. Using the food security scale in Table 1 ,

Table 1 Measurement scale for food security. Source: [27]

\begin{tabular}{llll}
\hline Dependence ratio & Number of meals per day & Scale of food insecurity (0-3) & $\begin{array}{l}\text { Category of food inse- } \\
\text { curity }\end{array}$ \\
\hline$\geq 0.5$ & $\leq 2$ & 3 & Totally insecure \\
$<0.5$ & $\leq 2$ & 2 & Highly insecure \\
$\geq 0.5$ & $>2$ & 1 & Moderately insecure \\
$<0.5$ & $>2$ & 0 & Secure \\
\hline
\end{tabular}


household food security status was categorized as: food secure, moderately food insecure, highly food insecure and totally food insecure.

\section{Results}

Socio-economic and demographic characteristics

\section{of households}

The average age of a household head was about 46 years. Household heads in the wetland communities had on average spent about 6 years in school. The mean household size was 8 people of which about half were above 18 years old. On average, the respondents lived within a range of $4 \mathrm{~km}$ from a market (Table 2).

Majority (86\%) of the households that participated in the study were male-headed. The most common occupation of the household heads (81\%) was small-scale farming, especially in Pallisa District. Most (93\%) of the households owned land and only a small proportion (17\%) lived in permanent houses. Slightly more than half (59\%) of the households had a member in a social group (Table 2).

\section{Number of meals consumed by households}

About $8 \%$ of the households consumed only one meal per day (Fig. 2). Majority of the households (75\%) in the wetland areas of Uganda consumed two meals per day. The rest of the households consumed at least three meals per day.

\section{Level of dependence in households adjacent to wetlands}

About $97 \%$ of the households lived with dependants. Nearly half of the households had at least two dependants (Fig. 3). The average number of dependants per household was five.

\section{Status of household food security}

More than $90 \%$ of the households in the wetland communities in the two districts were food insecure. Out of all the households, about half were totally food insecure, while some $42 \%$ were either moderately food insecure or highly food insecure. A small proportion (7\%) of households in the wetland areas were food secure (Table 3).

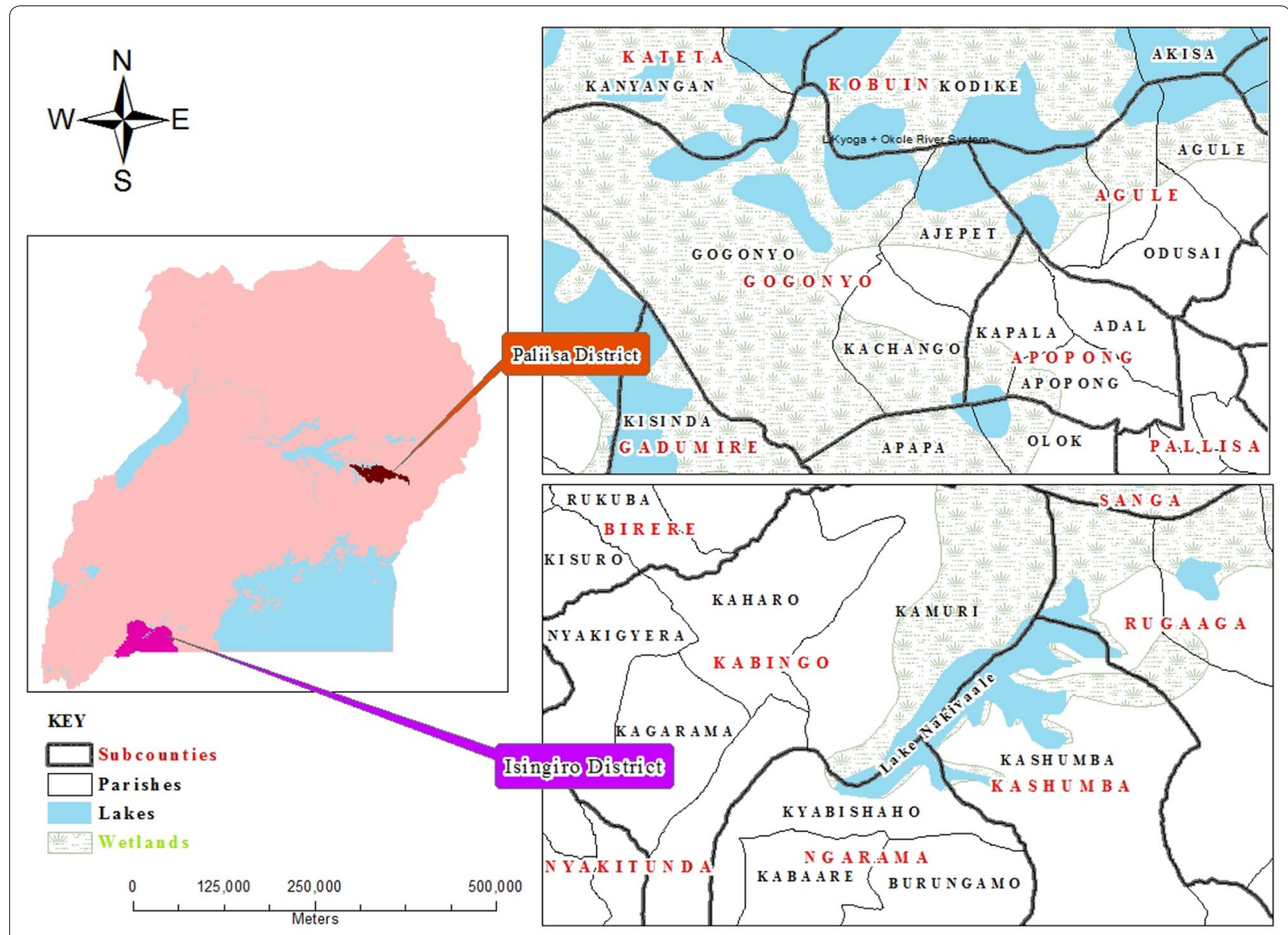

Fig. 1 Lake Kyoga basin wetlands in Pallisa and Lake Nakivale wetlands in Isingiro 
Table 2 Socio-economic and demographic characteristics of households $(N=520)$

\begin{tabular}{|c|c|c|c|}
\hline \multirow[t]{2}{*}{ Characteristic } & \multicolumn{3}{|l|}{ Mean (SD) } \\
\hline & Isingiro $(N=260)$ & Pallisa $(N=260)$ & Pooled $(N=520)$ \\
\hline Age of the household head (years) & $44.90(14.906)$ & $47.92(13.723)$ & $46.41(14.392)$ \\
\hline Education level of the household head (years) & $4.38(5.026)$ & $6.90(4.471)$ & $5.64(4.916)$ \\
\hline Number of resident people in the household & $6.62(3.153)$ & $9.64(4.691)$ & $8.13(4.271)$ \\
\hline Number of adults in the household ( $>18$ years old) & $3.08(2.516)$ & $4.18(2.294)$ & $3.63(2.468)$ \\
\hline Proximity to wetland $(\mathrm{km})$ & $1.86(1.937)$ & $1.19(1.289)$ & $1.53(1.677)$ \\
\hline Proximity to market (km) & $5.49(5.497)$ & $3.15(3.084)$ & $4.32(4.604)$ \\
\hline Land size (acres) & $5.44(18.116)$ & $1.55(1.457)$ & $3.49(12.986)$ \\
\hline Tropical Livestock Units (TLUs) & $4.34(12.973)$ & $1.88(1.997)$ & $3.12(9.354)$ \\
\hline \multirow[t]{2}{*}{ Period of residence in area (years) } & $22.10(16.230)$ & $36.52(18.948)$ & $29.88(19.134)$ \\
\hline & & $\%$ of households & \\
\hline \multicolumn{4}{|l|}{ Sex of household head } \\
\hline Female & 10 & 4 & 14 \\
\hline Male & 40 & 46 & 86 \\
\hline \multicolumn{4}{|l|}{ Main occupation of the household head } \\
\hline Small-scale farmer & 42 & 39 & 81 \\
\hline Off-farm occupation & 8 & 11 & 19 \\
\hline \multicolumn{4}{|l|}{ Household owns land } \\
\hline Yes & 45 & 48 & 93 \\
\hline No & 5 & 2 & 7 \\
\hline \multicolumn{4}{|l|}{ Household grows crops } \\
\hline Yes & 47 & 50 & 97 \\
\hline No & 3 & 0 & 3 \\
\hline \multicolumn{4}{|l|}{ Purpose of rearing livestock } \\
\hline Not commercial & 32 & 35 & 67 \\
\hline Commercial & 18 & 15 & 33 \\
\hline \multicolumn{4}{|l|}{ Household has a member in a social group } \\
\hline Yes & 35 & 24 & 59 \\
\hline No & 15 & 26 & 41 \\
\hline \multicolumn{4}{|l|}{ Type of house } \\
\hline Not permanent & 45 & 38 & 83 \\
\hline Permanent & 5 & 12 & 17 \\
\hline
\end{tabular}

\section{The relationship between socio-economic and demographic} characteristics of respondents

Bivariate analysis showed that there was a statistically significant association between household food security and the following factors: the study site (wetland systems or agro-ecological zone) $\left(\chi^{2}=15.758, d f=3, P=0.001\right)$, living in a permanent house $\left(\chi^{2}=16.1768\right.$, $d f=3$, $P=0.001)$, membership in a group $\left(\chi^{2}=7.942, d f=3\right.$, $P=0.047)$ and off-farm employment $\left(\chi^{2}=34.7931\right.$, $d f=3, P=0.000$ ) (Table 4 ). In contrast, the sex of household head, land ownership, crop production and commercial livestock production were not significantly associated with household food security.

A post hoc test for the Chi-square analysis revealed that among the households that lived in a permanent house, more moderately food insecure households were observed than expected $(P<0.001)$. In the same way, among the households headed by people whose main occupation was off farm, more moderately food insecure households $(P<0.001)$ and fewer highly food insecure households $(P<0.05)$ were observed than expected.

The one-way ANOVA and the Welch's ANOVA test, respectively, showed that there were no statistically significant differences between period of residence of a household in their location at the time of the study $(F=1.81, d f=3, P=0.1447)$, age of the household head $(F=1.055, d f=3, P=0.371)$ and household food security status (Table 5 ). On the other hand, the Kruskal-Wallis $H$ test showed that the median distance of households to the nearest output market $\left(\chi^{2}=27.816\right.$, 


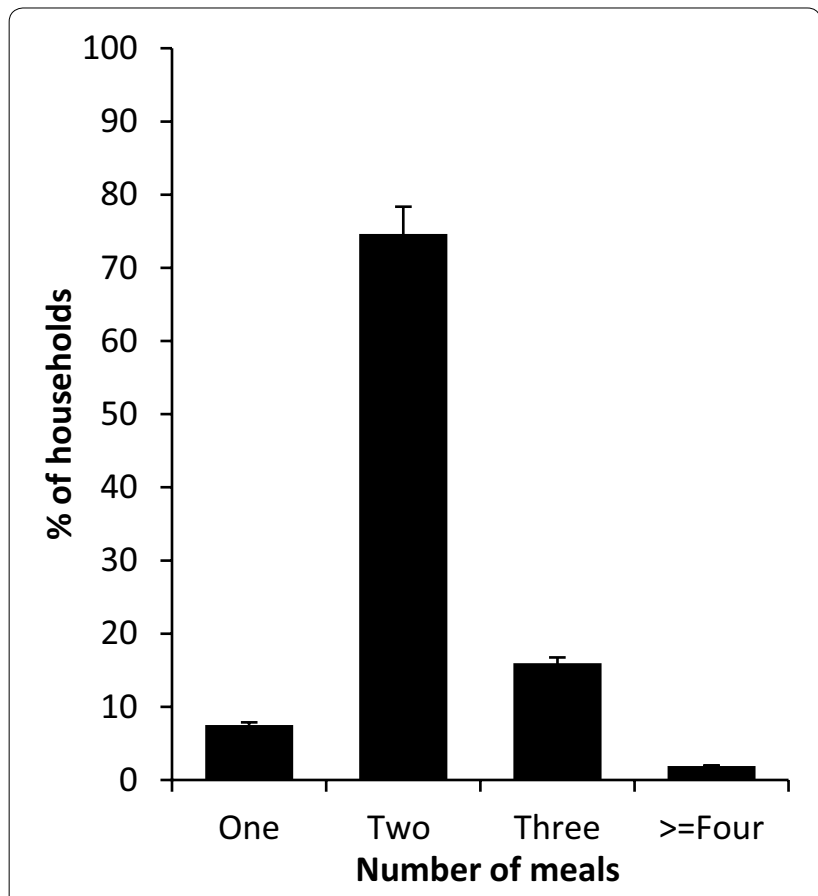

Fig. 2 Number of meals consumed by households per day

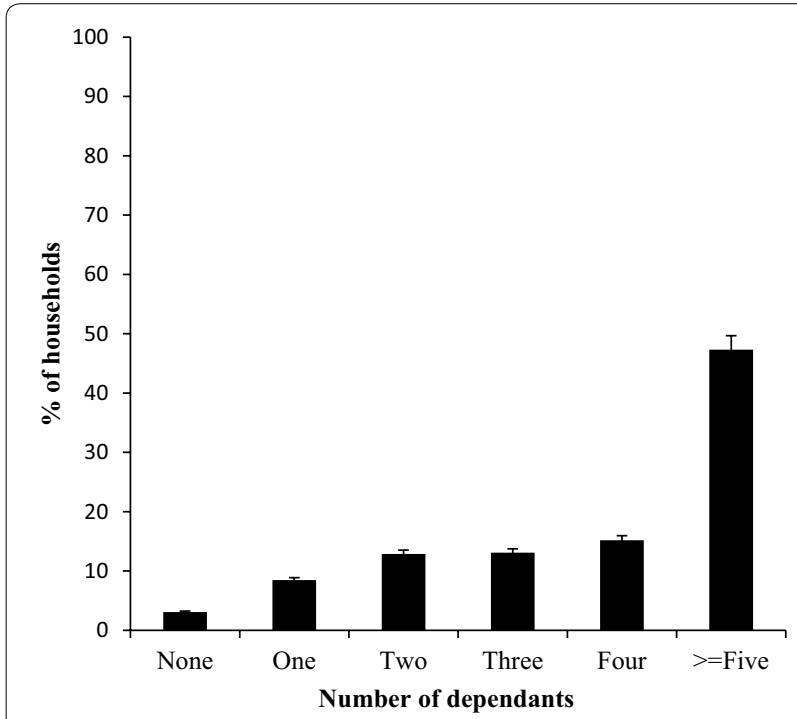

Fig. 3 Dependence in households in wetland areas of Uganda

$d f=3, P=0.0001$ ), the median household land size $\left(X^{2}=10.625, d f=3, P=0.0139\right)$, the median size of households $\left(\chi^{2}=9.349, d f=3, P=0.025\right)$ and the median TLU $\left(\chi^{2}=14.203, d f=3, P=0.0026\right)$ were all statistically significantly different between households belonging to different food security categories. A Dunn's post hoc test with Bonferroni correction to compare the distance to market between households by their food security groups indicated statistically significant differences between moderately food insecure (median $=2$ ) and highly food insecure (median $=4)$ households $(P=0.0000)$, and highly food insecure (median $=4$ ) and totally food insecure (median $=3$ ) households $(P=0.0004)$. Similarly, the median land size owned by moderately food insecure households (median $=1.62$ ) was statistically significantly different from households who were highly food insecure (median $=0.81)(P=0.0402)$. It was also noted from the post hoc test that the median TLU was statistically significantly different between the following food insecurity categories: food secure $($ median $=1.265)$ and highly food insecure (median $=0.415)(P=0.0061)$; food secure (median $=1.265$ ) and totally food insecure $($ median $=0.53)(P=0.0125)$; and moderately food insecure (median $=0.86$ ) and highly food insecure $($ median $=0.415)(P=0.0424)$.

The distributions and mean ranks of the number of years spent in school by the household head $\left(\chi^{2}=29.562\right.$, $d f=3, P=0.0001)$ and the number of adults in a household $\left(\chi^{2}=30.380, d f=3, P=0.0001\right)$ were statistically significantly different between households in different food security categories. A post hoc test showed statistically significant differences between the number of years spent in school by household head and the following food security categories: food secure households (mean rank $=347.161)$ and highly food insecure households (mean rank $=235.046)(P=0.0004)$; food secure households (mean rank $=347.161$ ) and totally food insecure households (mean rank $=249.708)(P=0.002)$; moderately food insecure households (mean rank $=328.924$ ) and highly food insecure households (mean rank $=235.046)(P=0.0002)$; moderately food insecure households (mean rank $=328.924)$ and totally food insecure households (mean rank $=249.708)(P=0.0014)$. Likewise, a post hoc test revealed statistically significant differences in the number of adults in a household between households with the following food security categories: food secure (mean rank $=190.897)$ and moderately food insecure (mean rank $=310.059)(P=0.0008)$; food secure (mean rank $=190.897$ ) and totally food insecure (mean rank $=282.381)(P=0.0034)$; moderately food insecure (mean rank $=310.059)$ and highly food insecure (mean rank $=221.265)(P=0.0004)$; highly food insecure (mean rank $=221.265)$ and totally food insecure $($ mean rank $=282.381)(P=0.0002)$.

\section{Discussion}

The study showed that majority (93\%) of the households were food insecure. The low level of food security could be attributed to limited availability of productive assets such as land for food production since the households 
Table 3 Status of household food security in Isingiro and Pallisa districts $(N=520)$

\begin{tabular}{lccc}
\hline $\begin{array}{l}\text { Status of food } \\
\text { security }\end{array}$ & \multicolumn{2}{l}{$\%(\boldsymbol{n})$ of households } \\
\cline { 2 - 4 } & Isingiro $(\boldsymbol{N = 2 6 0 )}$ & Pallisa $(\boldsymbol{N = 2 6 0 )}$ & $\begin{array}{l}\text { Pooled } \\
(\boldsymbol{N}=\mathbf{5 2 0})\end{array}$ \\
\hline $\begin{array}{l}\text { Secure } \\
\begin{array}{l}\text { Moderately } \\
\text { insecure }\end{array}\end{array}$ & $5(13)$ & $8.08(21)$ & $6.54(34)$ \\
Highly insecure & $27.69(72)$ & $14.62(38)$ & $11.35(59)$ \\
Totally insecure & $59.23(154)$ & $34.62(90)$ & $31.15(162)$ \\
\hline
\end{tabular}

live next to wetlands where access to wetland resources is restricted. Although about 93\% of the households owned land, the average land size owned by the households was small. Being predominantly engaged in small-scale farming on small pieces of land, it seems plausible to attribute food insecurity among the households to the limited land for food production. Otherwise, given that one does not have to own land to be food secure, food insecurity in wetland areas of Uganda can also be attributed to poverty, which limits household access to food from the markets and other forms of social and economic networks. Findings of the [8] seem to corroborate this view, owing to the fact that at least $40 \%$ of the people in Pallisa District, where wetlands have a wide coverage, lived below the poverty line. The attribution of food insecurity to poverty is further vindicated by the fact that TLU, used in this study as a proxy to income, was significantly different between food secure and highly food insecure households.

Table 4 Bivariate analysis of the relationship between socio-economic and demographic characteristics of respondents and household food security

\begin{tabular}{|c|c|c|c|c|c|c|c|}
\hline \multirow[t]{2}{*}{ Variable (code) } & \multicolumn{5}{|c|}{ Food security categories } & \multirow[t]{2}{*}{ Chi-square } & \multirow[t]{2}{*}{$P$ value } \\
\hline & Frequency (\%) & Secure $(N=34)$ & $\begin{array}{l}\text { Moderately inse- } \\
\text { cure }(N=59)\end{array}$ & $\begin{array}{l}\text { Highly insecure } \\
(N=162)\end{array}$ & $\begin{array}{l}\text { Totally insecure } \\
(N=265)\end{array}$ & & \\
\hline \multicolumn{8}{|l|}{ Wetland systems } \\
\hline Lake Nakivale (1) & $260(50)$ & $13(5.00)$ & $21(8.08)$ & $72(27.69)$ & $154(59.23)$ & & \\
\hline $\begin{array}{l}\text { Lake Kyoga Basin } \\
\text { (2) }\end{array}$ & $260(50)$ & $21(8.1)$ & $38(14.6)$ & $90(34.6)$ & $111(42.7)$ & 15.7580 & $0.001^{\mathrm{a}}$ \\
\hline \multicolumn{8}{|l|}{ Sex of household head } \\
\hline Female (0) & 74 (14.2) & $3(4.05)$ & $4(5.41)$ & $27(36.49)$ & $40(54.05)$ & & $0.248^{b}$ \\
\hline Male (1) & $446(85.8)$ & $31(6.95)$ & $55(12.33)$ & $135(30.27)$ & $225(50.45)$ & 1.332 & \\
\hline \multicolumn{8}{|l|}{ Land ownership } \\
\hline No $(0)$ & $37(7.1)$ & $1(2.70)$ & $4(10.8)$ & $11(29.70)$ & $21(56.8)$ & & \\
\hline Yes (1) & $483(92.9)$ & $33(6.83)$ & 55 (11.39) & $151(31.26)$ & $244(50.52)$ & 0.761 & $0.383^{b}$ \\
\hline \multicolumn{8}{|l|}{ Permanent house } \\
\hline No $(0)$ & $434(83.5)$ & $30(6.9)$ & $39(9.0)$ & $143(32.9)$ & $222(51.2)$ & & \\
\hline Yes (1) & $86(16.5)$ & $4(4.65)$ & $20(23.26)^{c}$ & 19 (22.09) & $43(50.00)$ & 16.1768 & $0.001^{\text {at }}$ \\
\hline \multicolumn{8}{|l|}{ Group membership } \\
\hline No $(0)$ & $213(41)$ & $10(4.70)$ & $17(8.0)$ & $65(30.5)$ & $121(56.8)$ & & \\
\hline Yes (1) & $307(59)$ & $24(7.80)$ & $42(13.7)$ & 97 (31.6) & $144(46.9)$ & 7.942 & $0.047^{\mathrm{a}}$ \\
\hline \multicolumn{8}{|l|}{ Crop production } \\
\hline $\mathrm{No}(0)$ & $14(2.7)$ & $0(0)$ & $0(0)$ & $5(35.7)$ & $9(64.3)$ & & \\
\hline Yes (1) & $506(97.3)$ & 6.72 & 11.66 & 31.03 & 50.59 & 2.003 & $0.157^{b}$ \\
\hline \multicolumn{8}{|l|}{ Livestock production } \\
\hline Non-commercial (0) & $349(67.1)$ & $20(5.70)$ & $33(9.50)$ & $113(32.4)$ & $183(52.0)$ & & \\
\hline Commercial (1) & $171(32.9)$ & 14 (8.19) & $26(15.20)$ & $49(28.65)$ & $82(47.95)$ & 5.3656 & $0.147^{\mathrm{a}}$ \\
\hline \multicolumn{8}{|l|}{ Off-farm employment } \\
\hline No (1) & $423(81.3)$ & $23(5.4)$ & $34(8.0)^{e}$ & $146(34.5)$ & $220(52)$ & & \\
\hline Yes (2) & $97(18.7)$ & $11(11.34)$ & $25(25.77)^{c}$ & $16(16.49)^{d}$ & $45(46.39)$ & 34.7931 & $0.000^{\text {at }}$ \\
\hline
\end{tabular}

Figures in parentheses are $\%$ of households

${ }^{+}$Post hoc test (standardized residual against Z-critical vales) statistically significant at: ${ }^{\mathrm{c}} P<0.001 ;{ }^{\mathrm{d}} P<0.01$; ${ }^{\text {e }} P<0.05$

a Pearson's Chi-square test for independence

b Kruskal-Wallis equality of populations rank test

c, d More/fewer households than expected 
Table 5 Bivariate analysis of the relationship between socio-economic and demographic characteristics of respondents and household food security

\begin{tabular}{|c|c|c|c|c|c|}
\hline \multirow[t]{3}{*}{ Variable } & \multicolumn{4}{|c|}{ Food security categories } & \multirow{3}{*}{$\begin{array}{l}\text { Kruskal-Wallis } H \text { test } \\
P \text { value }^{1,2}\end{array}$} \\
\hline & \multirow{2}{*}{$\begin{array}{l}\text { Secure }(N=34) \\
\text { Mean rank }(M)\end{array}$} & \multirow{2}{*}{$\begin{array}{l}\text { Moderately insecure } \\
(N=59) \\
\text { Mean rank (M) }\end{array}$} & \multirow{2}{*}{$\begin{array}{l}\text { Highly insecure } \\
(N=162) \\
\text { Mean rank (M) }\end{array}$} & \multirow{2}{*}{$\begin{array}{l}\text { Totally insecure } \\
(N=265) \\
\text { Mean rank (M) }\end{array}$} & \\
\hline & & & & & \\
\hline $\begin{array}{l}\text { Period of residence } \\
\text { (years)* }\end{array}$ & $29.536(17.165)$ & 35.755 (22.199) & $29.795(18.529)$ & $28.814(18.974)$ & $0.1447^{1}$ \\
\hline Age of household head* & $47.941(11.092)$ & $48.915(16.367)$ & $45.951(13.765)$ & $45.928(14.675)$ & $0.371^{2}$ \\
\hline Proximity to wetland ( $\mathrm{km})$ & $240.941(1)$ & $272.508(1)$ & $264.201(1)$ & $258.074(1)$ & 0.7722 \\
\hline Proximity to market (km) & $249.059(3)$ & $197.873(2)^{\mathrm{a}}$ & $306.843(4)^{\mathrm{ab}}$ & $247.583(3)^{b}$ & 0.0001 \\
\hline $\begin{array}{l}\text { Household land size } \\
\text { (acres) }\end{array}$ & 305.75 (1.8225) & $300.788(1.62)^{c}$ & $239.173(0.81)^{c}$ & $258.762(1.215)$ & 0.0139 \\
\hline $\begin{array}{l}\text { Number of adults } \\
\text { (>18 years) }\end{array}$ & $190.897(2)^{\text {de }}$ & $310.059(4)^{\mathrm{df}}$ & $221.265(2)^{\mathrm{fg}}$ & $282.381(3)^{\text {e.g. }}$ & $0.0001^{\mathrm{s}}$ \\
\hline Household size & $302.779(8)$ & $262.754(7)$ & $280.327(8)$ & $242.451(6)$ & $0.025^{\mathrm{ns}}$ \\
\hline $\begin{array}{l}\text { Education level of HH } \\
\text { (years) }\end{array}$ & $347.161(7)^{\mathrm{hi}}$ & $328.924(7)^{j k}$ & $235.046(5)^{\mathrm{hj}}$ & $249.708(5)^{\mathrm{ik}}$ & $0.0001^{\mathrm{s}}$ \\
\hline TLU & $331.059(1.265)^{\mathrm{lm}}$ & $299.822(0.86)^{\mathrm{n}}$ & $243.914(0.415)^{\ln }$ & $252.832(0.53)^{\mathrm{m}}$ & 0.0026 \\
\hline
\end{tabular}

Similar alphabetical letter superscripts indicate statistically significant differences in post hoc test

$M$ median, $\mathrm{HH}$ household head

*Mean (SD)

$P$ value ${ }^{1,2}, 1$ one-way ANOVA, ${ }^{2}$ Welch ANOVA

a Significantly different between moderately food insecure and highly food insecure, ${ }^{\mathbf{b}}$ significantly different between highly food insecure and totally food insecure; ${ }^{\mathbf{c}}$ significantly different between moderately food insecure and highly food insecure, ${ }^{\mathbf{d}}$ significantly different between food secure and moderately food insecure, ${ }^{e}$ significantly different between food secure and totally food insecure, ${ }^{f}$ significantly different between moderately food insecure and highly food insecure, ${ }^{g}$ significantly different between highly food insecure and totally food insecure, ${ }^{\mathrm{h}}$ significantly different between food secure and highly food insecure, ${ }^{\mathrm{i}}$ significantly different between food secure and totally food insecure, ${ }^{j}$ significantly different between moderately food insecure and highly food insecure, ${ }^{k}$ significantly different between moderately food insecure and totally food insecure, ' significantly different between food secure and highly food insecure, $\mathrm{m}$ significantly different between food secure and totally food insecure, ${ }^{n}$ significantly different between moderately food insecure and highly food insecure, ${ }^{5}$ distributions not similar for food security categories (other distributions are similar), ${ }^{\text {ns }}$ post hoc test not statistically significantly different

Bivariate analysis showed that wetland system/agro-ecological zone, the type of house household lived in and the main occupation of household being off farm were significantly associated with the status of household food security. A post hoc test indicated that living in a permanent house was particularly significantly associated with moderate food insecurity. Living in a permanent house means that households invest some of their resources in physical infrastructure, although resources are not enough to be food secure. Some of the households living in permanent houses especially in trading centres could be renting their houses, indicating a shift in location or lack of assets to construct their own houses. Such expenditures could be the reason why households in permanent houses are moderately food insecure. Living in rentals especially in trading centres or landing sites could be attributed to off-farm low-wage employment, in which case households in this category depend on other activities apart from agriculture and therefore do not have enough food for consumption.

The occupation of a household head was significantly associated with household food insecurity. This implies that access to food by households whether through own food production or purchases and other means was not sufficient for the households. Low food production on farm could be a result of land shortage, land degradation or unconducive weather for food production. Being wetland communities, it could also be attributed to restrictions on use of wetlands for food production, especially for those who live close to wetlands.

Although the post hoc test revealed a statistically significant association between the main occupation of a household head being off farm and moderate food insecurity, it also indicated that fewer households in the same occupation category were highly food insecure. This suggests that households with off-farm occupation are just marginally food insecure with the potential of becoming food secure. Households in this category could be refugees in the Lake Nakivale area who might be getting insufficient food rations from the United Nations High Commission for Refugees (UNHCR), or households whose members have moved to wetland areas for economic reasons but currently engage in low-wage activities. Previous studies suggest that wetlands attract and support the livelihoods of migrants $[44,45]$. 
With off-farm occupation, especially for women in Uganda who are generally responsible for food preparation [46], it is possible that people who provide productive labour force within the households spend a considerable portion of their time away from home, thus affecting the number of meals prepared for the household. Again, with the pastoralist background of several households in Isingiro District, household members could be spending a significant portion of their time herding livestock away from home, thereby compromising food consumption in their homes.

Land ownership, crop production and commercial livestock production were not significantly associated with household food security. Land ownership might not have influenced food security because people have the opportunity to use wetlands communally for a range of purposes such as grazing of livestock, harvesting of wetland resources such as firewood, water, papyrus and fish. After all, the wetland policy for Uganda allows traditional use of wetlands for food security, including wetland edge gardening for production of crops such as vegetables [26]. Landless households were also able to rent land for crop production, especially in Isingiro District where commercial land transactions were common. Crop production was not associated with food security probably because of the small-scale nature.

The Kruskal-Wallis $H$ test showed that distance to market significantly influenced food insecurity, albeit with contradicting results. While highly food insecure households lived far away from markets compared with moderately food insecure households, the totally food insecure households were surprisingly closer to markets than the highly food insecure households. The study argues that the totally food insecure households who lived closer to markets could be households that lacked assets such as land for agriculture and therefore strategically settled at places where off-farm economic activities were available. Since the distance to market for totally food insecure households was shorter than for highly food insecure households, it is argued that the totally food insecure households have limited access to market because of poverty. Alternatively, exposure to produce markets can also tempt households who have no other sources of income to sale off food and remain with only little food reserves.

Generally, the higher the land size, household size and education level of the household head, the less food insecure the households were (Table 5). Land is a factor of production, so its availability enhances household's opportunities to produce food and engage in other income generating activities to purchase food. Availability of land is also a possible means for households to create social capital which is useful for food security.
Households headed by educated people were food secure compared with their counterparts because education empowers households through access to knowledge and information on recommended food security and nutrition practices. In addition, education opens avenues for alternative employment and hence additional income to access food, let alone the social capital accumulated during the process of education and employment outside farming which can also promote food security. While households with bigger size were generally food secure, those with a high number of adults were insecure. This implies low labour productivity of adults due to unemployment caused by lack of land and other assets required for farming, or due to poor working habits. This also means that households with large size are food secure because they engage children in productive activities such as livestock herding, collection of resources such as firewood and water from the wetlands and cooking which all contribute to food security. In addition, the presence of children in households appears to be a source of influence for such households to regularly prepare meals, thus improving their food security. Households with higher median TLU were food secure compared with those that had low TLU because livestock are assets that can be used to smooth food consumption in times of food shortage [27, 28]. Besides, livestock products can also be consumed for food.

\section{Conclusion and recommendations}

Households in the wetland areas in this study are generally food insecure. Although local inhabitants of wetland areas in Isingiro District may be economically better off than those in Pallisa District, the former wetland areas are commonly infiltrated by the poor and marginalized groups, whose presence has a bearing on food insecurity in these areas. Much as pastoral communities around wetlands in Isingiro normally have a wealth of livestock, for them, having sufficient economic resources does not necessarily translate into food security, and normally so because they often adhere to a tradition of heavy dependence on livestock products for food.

Beyond a moral, legal or human rights basis of concern for food security, the high prevalence of food insecurity in wetland areas should be considered a recipe for adversity in these areas on two grounds: (1) degradation of wetlands as the food insecure households, might as expected, become more dependent on wetlands for food security and thus possibly reverse progress already made in wetland conservation, yet more restrictions on wetland use could worsen food insecurity; and (2) from a public health point of view, food insecurity in the majority of the households in wetland communities is bound to worsen the already existing public health concerns in 
wetland areas, especially the spread of HIV/AIDS and other sexually transmitted diseases in fishing communities, where fisher folks are notoriously keen to take advantage of food insecurity and vulnerability by trading fish or cash income for sex mostly with women and girls as in reality is already the case.

Bearing in mind the likely consequences, it is recommended that initiatives to support food security integrate both wetland conservation and public health. Since wetlands are fragile, food production outside wetlands could be enhanced through sustainable intensification in the following ways: (1) promotion of improved and drought tolerant crop varieties; (2) promotion of water conservation technologies; and (3) support for cage fish farming. Sensitization on food security should transcend the boundaries of food availability and accessibility to food utilization and nutrition and related aspects of public health, including family planning.

Although this study addresses the access dimension of food security, some caution ought to be exercised when using it to develop food security initiatives. Basing on the method for measuring food security and factoring in the computation of dependence ratio, the results of the study could be more useful for addressing gaps in food security that are related to unemployment, low labour efficiency, poor food utilization and nutrition practices and poverty.

We recommend that future studies employing this method include gender dimensions of food security as one of the explanatory variables because the number of meals consumed by households per day could be affected by gender differentials. In addition, more studies of this kind could be carried out in other wetland adjacent areas in Uganda to integrate any cultural influences.

\section{Abbreviations}

ILRI: International Livestock Research Institute; MEA: Millennium Ecosystem Assessment; TLU: Tropical Livestock Unit; WFP: World Food Programme; WMD: Wetland Management Department; UNHCR: United Nations High Commission for Refugees.

\section{Authors' contributions}

FY designed the study, collected data, analysed data and participated in writ ing the manuscript. NT designed the study and participated in the write up. $\mathrm{BB}$ designed the study and participated in the write up. All authors read and approved the final manuscript.

\section{Authors' information}

$\mathrm{FY}$ is an Assistant Lecturer in the Department of Environmental Management, School of Forestry, Environmental and Geographical Sciences, College of Agricultural and Environmental Sciences, Makerere University. NT is an Associate Professor in the Department of Extension and Innovation Studies, School of Agricultural Sciences, College of Agricultural and Environmental Sciences, Makerere University. BB is a Professor of Agricultural Economics, Department of Agribusiness and Natural Resource Economics, School of Agricultural Sciences, College of Agricultural and Environmental Sciences, Makerere University.

\section{Author details}

1 Department of Forestry, Biodiversity and Tourism, School of Forestry, Environmental and Geographical Sciences, Makerere University, P.O Box 7062, Kampala, Uganda. ${ }^{2}$ Department of Environmental Management, School of Forestry, Environmental and Geographical Sciences, Makerere University, P.O Box 7062, Kampala, Uganda. ${ }^{3}$ Department of Extension and Innovation Studies, School of Agricultural Sciences, Makerere University, P.O Box 7062, Kampala, Uganda. ${ }^{4}$ Department of Agribusiness and Natural Resource Economics, School of Agricultural Sciences, Makerere University, P.O Box 7062, Kampala, Uganda.

\section{Acknowledgements}

We are grateful to Deuson Kajumbe, Abdu Kamoga, Namuddu Rehema Lwanga, William Muwesi, Nantabo Rose Mary, Odelle John Patrick and Kadioli Ben Fred for helping in data collection. Thanks to Christopher Sebatta for the support during data analysis. We also express our gratitude to the local communities for their cooperation during field work.

\section{Competing interests}

The authors declare that they have no competing interests.

\section{Availability of data and materials}

The datasets used during the current study are available from the corresponding author on reasonable request and with permission from co-authors.

\section{Consent for publication}

Not applicable.

\section{Ethics approval and consent to participate}

The study was conducted with the consent of local authorities and the authorities at Nakivale Refugee Settlement areas. The consent of every respondent was obtained prior to data collection. It was made clear that the study was meant for academic purposes.

\section{Funding}

We would like to thank the International Development Research Centre (IDRC) for providing funding for this study. Thanks to DAAD for the supplementary funding support.

\section{Publisher's Note}

Springer Nature remains neutral with regard to jurisdictional claims in published maps and institutional affiliations.

Received: 22 May 2017 Accepted: 16 November 2017 Published online: 27 November 2017

References

1. United Nations. The millennium development goals report. United Nations; 2015. p. 72

2. FAO. The state of food security and nutrition in the world. Building resilience for peace and food security. Rome: Food and Agriculture Organization of the United Nations; 2017. p. 2017.

3. Chappell MJ, LaValle LA. Food security and biodiversity: Can we have both? An agroecological analysis. Agric Human Values. 2011;28(1):3-26.

4. Sen A. Poverty and famines: an essay on entitlement and deprivation. Oxford, United Kingdom: Oxford University Press; 1981. p. 257.

5. MEA. Ecosystems and human well-being: wetlands and water synthesis. Washington: World Resources Institute; 2005.

6. Turyahabwe N, Kakuru W, Tweheyo M, Tumusiime DM. Contribution of wetland resources to household food security in Uganda. Agric Food Secur. 2013;2(1):5.

7. Dixon A, Wood A. Sustainable wetland management for food security and rural livelihoods in south-west Ethiopia: the interaction of local knowledge and institutions, government policies and globalisation. In: Paper prepared for presentation at the "Seminaire sur l'amenagement des zones marecageuses du Rwanda", at the National University of Rwanda; 2001. p. 1-15 
8. WMD, MOWE, UBOS, ILRI, WRI. Mapping a better future how spatial analysis can benefit wetlands and reduce poverty in Uganda. Washington: World Resources Institute; 2009. p. 51.

9. Malan HL, Appleton CC, Day JA, Dini J. Wetlands and invertebrate disease hosts: Are we asking for trouble? Water SA. 2009;35(5):753-68.

10. Asiki G, et al. HIV and syphilis prevalence and associated risk factors among fishing communities of Lake Victoria, Uganda. Sex Transm Infect. 2011;87(6):511-5.

11. Tsai AC, Bangsberg DR, Emenyonu N, Senkungu JK, Martin JN, Weiser SD. The social context of food insecurity among persons living with HIV/AIDS in rural Uganda. Soc Sci Med. 2011;73(12):1717-24.

12. Weiser SD, Tuller DM, Frongillo EA, Senkungu J, Mukiibi N, Bangsberg DR. Food insecurity as a barrier to sustained antiretroviral therapy adherence in Uganda. PLoS ONE. 2010;5(4):e10340.

13. Chapoto A, Jayne TS. Impact of AIDS-related mortality on farm household welfare in Zambia. Chic J. 2008;56(2):327-74.

14. The State of Food Insecurity in the World 2001. Rome; 2002.

15. DFID. Sustainable livelihoods guidance sheets. London, UK: Department for International Development (DFID); 2001. p. 146.

16. Pinstrup-Andersen P. Food security: definition and measurement. Food Sec. 2009; 1(1):5-7.

17. Anderson SA. Core indicators of nutritional state for difficult-to-sample populations. J Nutr. 1990;120(Suppl):1559-600.

18. Hadley C, Zodhiates A, Sellen DW. Acculturation, economics and food insecurity among refugees resettled in the USA: a case study of West African refugees. Public Health Nutr. 2007;10(4):405-12.

19. Peterman JN, Silka L, Bermudez OI, Wilde PE, Rogers BL. Acculturation, education, nutrition education, and household composition are related to dietary practices among Cambodian refugee women in Lowell, MA. Am Diet Assoc. 2011;111(9):1369-74.

20. Hofferth SL. Persistance and change in the food security of families with children, 1997-1999. Department of Family Studies, University of Maryland; 2004. p. 27.

21. Aggarwal $\mathrm{S}$, Elbow K. The role of property rights in natural resource management, good governance and empowerment of the rural poor. United States Agency for International Development, Burlington; 2006. p. 40.

22. McKinney P. Comprehensive food security and vulnerability analysis: Uganda. United Nations World Food Programme (WFP). Rome, Italy; 2009 p. 98.

23. Smith LC, Alderman H, Aduayom D. Food insecurity in Sub-Saharan Africa new estimates from household expenditure surveys. Washington: International Food Policy Research Institute; 2006.

24. The Republic. Uganda Census of Agriculture 2008/09 at a Glance page 0; 2008. p. $0-21$

25. UBOS. Summary Report on Uganda Census of Agriculture 2008/2009. Volume I. Summary Report. Kampala, Uganda; 2010. p. 62.

26. Ministry of Natural Resources. National policy for the conservation and management of wetland resources. Uganda; 1995. p. 28.

27. Babu S, Sanyal P. Food security, poverty and nutrition policy analysis: statistical methods and applications. 1st ed. London: Academic Press; 2009.
28. Babu SC, Gajanan SN, Sanyal P. Food security, poverty and nutrition policy analysis: statistical methods and applications. 2nd ed. London: Academic Press; 2014.

29. United Nations. Transforming our world: the 2030 agenda for sustainable development, no. 1. United Nations; 2015. p. 1-36.

30. Ebanyat P, de Ridder N, de Jager A, Delve RJ, Bekunda MA, Giller KE. Drivers of land use change and household determinants of sustainability in smallholder farming systems of Eastern Uganda. Popul Environ. 2010;31(6):474-506.

31. Ramsar Secretariat. Uganda adds nine new Ramsar sites. News; 2006.

32. Alelign $A$, Yemshaw $Y$, Teketay $D$, Edwards $S$. Socio-economic factors affecting sustainable utilization of woody species in Zegie Peninsula, northwestern Ethiopia. Trop Ecol. 2011;52(1):13-24.

33. Bartlett JE, Kotrlik JW, Higgins CC. Organizational research: determining appropriate sample size in survey research. Inf Technol Learn Perform J. 2001;19(1):43-50.

34. Mohamadpour M, Sharif ZM, Keysami MA. Food insecurity, health and nutritional status among sample of palm-plantation households in Malaysia. J Health Popul Nutr. 2012;30(3):291-302.

35. Haddad L, Kennedy E, Sullivan J. Choice of indicators for food security and nutrition monitoring. Food Policy. 1994;19(3):329-43.

36. Loichinger AE, Hammer B, Prskawetz A, Freiberger M, Wien TU. Economic dependency ratios: present situation and future scenarios working paper no 74 economic dependency ratios: present situation and future scenarios. 2014. p. 74

37. Uganda Bureau of Statistics. The national population and housing census 2014-main report. Kampala; 2016

38. Zamaro G, Green G, Tsouros A, Chiavon E. A new model dependency ratio for European cities. Ital. J. Public Health. 2008;5(3):217-27.

39. Titus B, Adetokunbo G. An analysis of food security situation among Nigerian urban households: evidence from Lagos state, Nigeria. J Cent Eur Agric. 2007;8(3):397-406.

40. Mayanja MN, Rubaire-Akiiki C, Greiner T, Morton JF. Characterising food insecurity in pastoral and agro-pastoral communities in Uganda using a consumption coping strategy index. Pastoralism. 2015;5:1-11.

41. StataCorp. Stata statistical software release 13. College Station: StataCorp LP; 2013.

42. Corp IBM. IBM SPSS statistics for windows, version 23. Armonk: IBM Corp; 2015.

43. Laerd Statistics. The Welch ANOVA (homogeneity of variances was violated) Authors; 2017.

44. Lamsal P, Pant KP, Kumar L, Atreya K. Sustainable livelihoods through conservation of wetland resources: a case of economic benefits from Ghodaghodi Lake, western Nepal. Ecol Soc 2015:20(1):10.

45. Halima KH, Munishi KP. Contribution of wetlands to household income and food security in the Nyumba Ya Mungu wetland system, northern Tanzania. Tanzan J For Nat Conserv. 2009;79(2):99-108.

46. Lasky D, Becerra E, Boto W, Otim M, Ntambi J. Obesity and gender differences in the risk of type 2 diabetes mellitus in Uganda. Nutrition. 2002;18(5):417-21.

\section{Submit your next manuscript to BioMed Central and we will help you at every step:}

- We accept pre-submission inquiries

- Our selector tool helps you to find the most relevant journal

- We provide round the clock customer support

- Convenient online submission

- Thorough peer review

- Inclusion in PubMed and all major indexing services

- Maximum visibility for your research

Submit your manuscript at www.biomedcentral.com/submit 